\title{
Studies on Melamine Resin. VII. Kinetics of the Acid-Catalyzed Condensation of Di- and Trimethylolmelamine*
}

\author{
Kenji Sato and Takanobu Naito \\ Department of Industrial Chemistry, Science University of \\ Tokyo, Noda, Chiba, Japan. \\ (Received January 10, 1973)
}

\begin{abstract}
Initial-stage kinetics for the condensation of di- and trimethylolmelamine (M2F and M3F respectively) have been studied in an aqueous dimethylsufoxide media with $\mathrm{pH}$ ca. $1-9$. The main results were as follows.

(1) Regardless of $\mathrm{pH}$, the initial rate was given by $R_{0}=k[\mathrm{MnF}]^{2}(n=2$ or 3$)$ and $k$ is the overall rate constant. The values of $k$ in the $\mathrm{pH}$ range of $c a .1-9$ were obtained.

(2) The observed curves ( $k$ vs. $\mathrm{pH}, \log k v s . \mathrm{pH}$, and $k$ vs. $\left[\mathrm{H}^{+}\right]$) were compared with the corresponding calculated curves based on the rate equation. Consequently, in the presence of the acid, it was revealed that for an $S \equiv[\text { hydrochloric acid }]_{0} /[\mathrm{M} 2 \mathrm{~F}]_{0}$ or $[\mathrm{M} 3 \mathrm{~F}]_{0}$ ratio less than $1.0(\mathrm{pH} c a .2-7)$ the main reaction at the early stage of the condensation is the reaction between the methylolmelamine molecule and the conjugate acid; furthermore for $S>1.0-1.2(\mathrm{pH}<c a$. 2) the main condensation would be the reaction between the conjugate acid themselves.

(3) At equal $S$, the $k$ for $\mathrm{M} 3 \mathrm{~F}$ is remarkably larger than that for M2F. This is opposite to the rates of mono- and dimethylolurea. The mechanism was interpreted.

KEY WORDS Methylolmelamine/Melamine Resin / Condensation/

Methylene Linkage / Amino Resin / Kinetics / Acid Catalyst /
\end{abstract}

As is well-known, urea and melamine (M) resins are the most prominent members of amino resins. There have been a number of kinetic studies ${ }^{1 \mathrm{a}-\theta}$ on the condensation (the formation of methylene linkages) of methylolurea. On the other hand, condensation of methylolmelamine has been studied by Kitagawa, ${ }^{2}$ Wohnsiedler, ${ }^{3}$ Koeda, ${ }^{4}$ and Yoshimi, et al., ${ }^{5}$ and recently by Sato $^{6 \mathrm{a}, \mathrm{b}}$ who reported in a previous work using an aqueous dimethylsulfoxide (DMSO) media. However, studies on kinetics of the condensation of methylolmelamine have not yet been reported. For this reason, condensations of di- and trimethylolmelamine (M2F and M3F respectively) were kinetically studied in detail at the early stages, using an aqueous-DMSO media in the $\mathrm{pH}$ range of $c a$. $1-9$.

The present report deals with the important relationship between the condensation rate and

* Presented at the 16th Annual Meeting of the Chemical Society of Japan, April, 1963, and at SPSJ 20th Symposium on Macromolecules, November, 1971. the acidity of the solution, since the acidity relates to some probable mechanism at the early stage of the condensation.

In this paper, [ ] denotes the concentration, [ ] $]_{0}$, the initial concentration, and $S$, the molar ratio of [hydrochloric acid $]_{0} /[\mathrm{M} 1.97 \mathrm{~F}]_{0}$ or $[\mathrm{M} 2.95 \mathrm{~F}]_{0}$.

\section{EXPERIMENTAL}

\section{Materials}

The method used in the purification of $M$ and DMSO has been described in a previous paper. ${ }^{6 \mathrm{~b}}$ Preparation of $M 1.97 F$ and $M 2.95 F^{3}$

The present method ${ }^{3}$ differs from that reported previously., ${ }^{4,6 \mathrm{~b}}$

Preparation of $M 1.97 F$. A mixture of $1600 \mathrm{ml}$ (ca. $22 \mathrm{~mol}$ ) of commercial formaline (F) (ca. $37 \mathrm{wt} \%)$ and $800 \mathrm{ml}$ of water was adjusted at $\mathrm{pH} 9.0-9.5$ with $0.1-N$ sodium hydroxide, and heated to $70^{\circ} \mathrm{C}$; then, $1.26 \mathrm{~kg}(10 \mathrm{~mol})$ of $\mathrm{M}$ was added with stirring, and reaction temperature was kept at $70^{\circ} \mathrm{C}$ until the $\mathrm{M}$ was almost dis- 
solved (ca. $20 \mathrm{~min}$ ). The turbid solution thus obtained was decanted to remove the small amount of insoluble substance, quenched with ice water, and left standing overnight. The precipitate produced was washed with methanol and ether, and dried in vacuo. Yield was $1.40 \mathrm{~kg}$.

Preparation of $M 2.95 \mathrm{~F}$. The method was almost the same as that of M1.97F: $2300 \mathrm{ml}$ (ca. 31 moles) of commercial $\mathrm{F}, 600 \mathrm{~m} l$ of water and $1.26 \mathrm{~kg}(10 \mathrm{~mol})$ of $\mathrm{M}$ were used. Yield was $1.81 \mathrm{~kg}$. These yields were remarkably better than those reported previously., ${ }^{4,6}$

Results of the analysis ${ }^{2,7}$ show that the molar ratios of the combined $\mathrm{F}$ to $\mathrm{M}$ were 1.97 and 2.95 , and that weight per cents of water were 0.78 and 2.20 respectively. The compositions of the sample were thus approximately M2F and $\mathrm{M} 3 \mathrm{~F}$. They will be described as M1.97F and $\mathrm{M} 2.95 \mathrm{~F}$.

A Typical Procedure for the Rate Measurements All investigations were carried out with $35^{\circ} \mathrm{C}$ as the reaction temperature, at a constant volume ratio of $\mathrm{DMSO} / \mathrm{H}_{2} \mathrm{O}$.

Initially, $4.66 \mathrm{~g}(0.025 \mathrm{~mol})$ of M1.97F or $5.49 \mathrm{~g}$ $(0.025 \mathrm{~mol})$ of $\mathrm{M} 2.95 \mathrm{~F}$ was dissolved to $250 \mathrm{ml}$ by using an aqueous DMSO solution (the volume ratio, 1/4). On the other hand, a mixture of $30 \mathrm{~m} l$ of DMSO and an appropriate amount of hydrochloric acid was diluted to $50 \mathrm{ml}$ using distilled water; thus, the volume ratio of DMSO/ $\mathrm{H}_{2} \mathrm{O}$ was made almost the same as that of the $\mathrm{M} 1.97 \mathrm{~F}$ or $\mathrm{M} 2.95 \mathrm{~F}$ solution, since dilution of DMSO with water is considerably exothermic. Then, the two solutions were respectively kept in a thermostat regulated at $35^{\circ} \mathrm{C}$, followed by mixing with each other (Table I, no. $1-24$ for M1.97F, and Table II, no. 32-52 for M2.95F).

Aliquots were analyzed by the iodometric and the sulfite methods, the $\mathrm{pH}$ being measured by a glass-electrode $\mathrm{pH}$-meter, as previously reported. ${ }^{6 \mathrm{~b}, 8}$

\section{An Estimation of the Initial Rate}

The methylene linkage formed was evaluated as previously $^{6 b}$ reported. Figure 1 shows some typical examples of the concentration of methylene linkage formed vs. time. The initial rate $R_{0}$ was computed from the slope of the curve of methylene linkage vs. time at time zero.

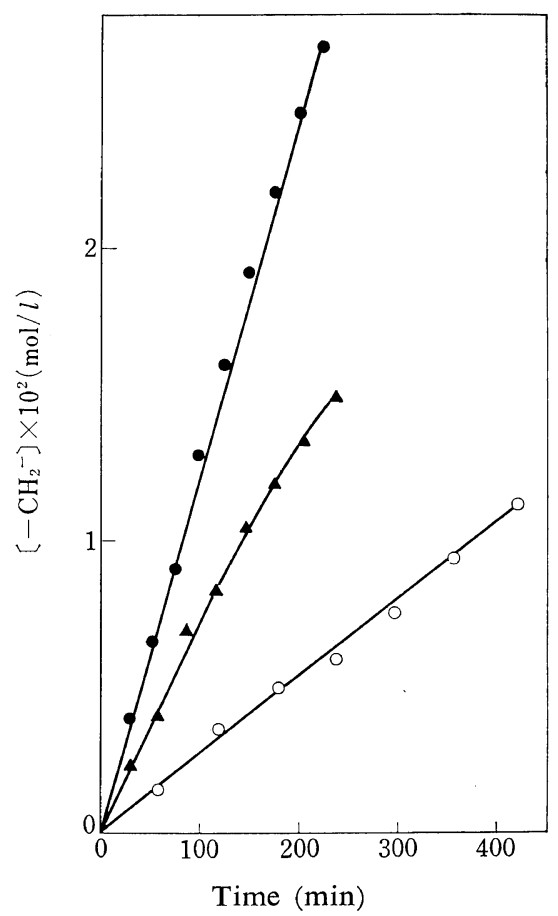

Figure 1. The methylene linkage formed $v s$. reaction time: $\bigcirc$, Table I expt1 no. 4; ○, no. 7; $\boldsymbol{\Delta}$, no. 16 .

\section{RESULTS AND DISCUSSION}

\section{Reaction Order and the Calculation of $k$}

The rate was measured at various concentration

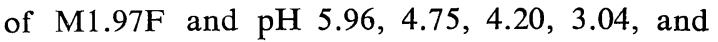
2.07 respectively. As Figure 2 a shows, the plots of $\log R_{0} v s . \log [\mathrm{M} 1.97 \mathrm{~F}]_{0}$ gave straight lines and the slopes $(\tan \alpha)$ were 2.0 regardless of the $\mathrm{pH}$. Accordingly, the reaction was of second order. The same was true for M2.95F, as shown in Figure $2 \mathrm{~b}$. It follows that

$$
R_{0}=k[\mathrm{MnF}]^{2}, \quad n=1.97 \text { and } 2.95
$$

where $k$ denotes the overall rate constant.

The values of $k$ for $\mathrm{M} 1.97 \mathrm{~F}$ were calculated by the use of eq 1 , and are shown in Table I together with the acidity of the solution $(S, 0-$ $6.901 ; \mathrm{pH}, c a .1-9)$, and those for $\mathrm{M} 2.95 \mathrm{~F}$, in Table II ( $S, 0-6.129 ; \mathrm{pH}, c a .1-9)$. In these Tables, no. 25-31 and no. 53-62 show respectively the values which corresponded to more concentrated M1.97F and M2.95F, since their rate was slow at $\mathrm{pH}<c a .3$. 
K. SAto and T. Naito
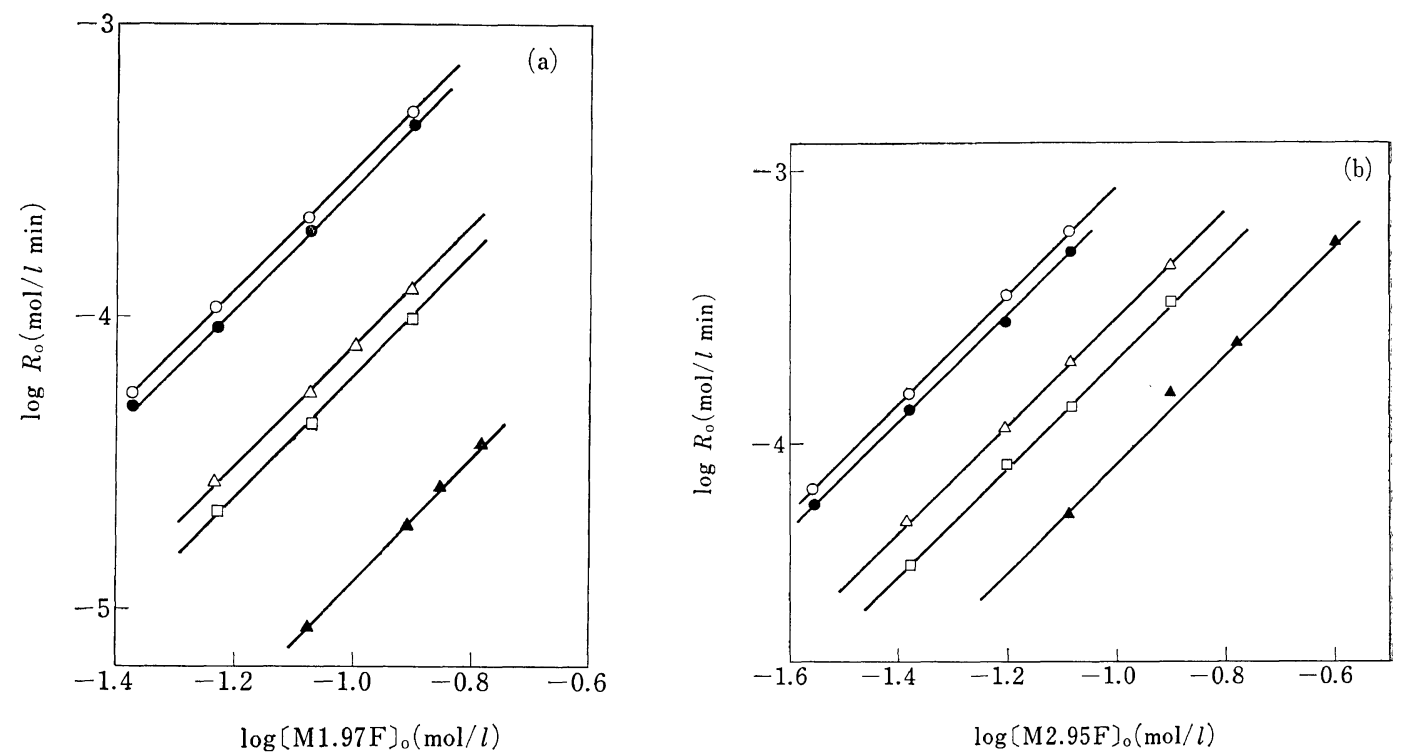

Figure 2. The relationship between $\log R_{0}$ and $\log [\mathrm{M} 1.97 \mathrm{~F}]_{0}$ or $\log [\mathrm{M} 2.95 \mathrm{~F}]_{0}$ : (a) for $\mathrm{M} 1.97 \mathrm{~F} ; \square$, $\mathrm{pH}$ 5.96;, $\mathrm{pH} 4.75 ; \bigcirc, \mathrm{pH} 4.20 ; \triangle, \mathrm{pH} 3.04 ;$ $\mathrm{pH} 4.15 ; \bigcirc, \mathrm{pH} 3.72 ; \triangle, \mathrm{pH} 2.84 ; \Delta, \mathrm{pH} 2.10$.

Table I. The value of $k$ for $\mathrm{M} 1.97 \mathrm{~F}$ at $35^{\circ} \mathrm{C}$ (The effect of acidity)

\begin{tabular}{|c|c|c|c|c|}
\hline $\begin{array}{c}\text { Exptla }^{\mathrm{a}} \\
\text { no. }\end{array}$ & $\begin{array}{l}{[\mathrm{HCl}]_{0} /} \\
{[\mathrm{M} 1.97 \mathrm{~F}]_{0},} \\
\text { molar ratio }\end{array}$ & $\mathrm{pH}$ & $\begin{array}{l}{\left[\mathrm{H}^{+}\right],{ }^{\mathrm{b}}} \\
\mathrm{mol} / \mathrm{l}\end{array}$ & $k, 1 / \mathrm{mol} \min$ \\
\hline 1 & 0.000 & 8.62 & $2.40 \times 10^{-9}$ & 0.00 \\
\hline 2 & 0.006 & 7.37 & $4.27 \times 10^{-8}$ & $1.21 \times 10^{-4}$ \\
\hline 3 & 0.021 & 6.76 & $1.74 \times 10^{-7}$ & $1.50 \times 10^{-3}$ \\
\hline 4 & 0.051 & 6.34 & $4.57 \times 10^{-7}$ & $3.67 \times 10^{-3}$ \\
\hline 5 & 0.095 & 6.00 & $1.00 \times 10^{-6}$ & $6.25 \times 10^{-3}$ \\
\hline 6 & 0.193 & 5.60 & $2.51 \times 10^{-6}$ & $1.28 \times 10^{-2}$ \\
\hline 7 & 0.292 & 5.29 & $5.13 \times 10^{-6}$ & $1.77 \times 10^{-2}$ \\
\hline 8 & 0.393 & 5.01 & $9.78 \times 10^{-6}$ & $2.32 \times 10^{-2}$ \\
\hline 9 & 0.491 & 4.73 & $1.86 \times 10^{-5}$ & $2.83 \times 10^{-2}$ \\
\hline 10 & 0.583 & 4.44 & $3.63 \times 10^{-5}$ & $3.23 \times 10^{-2}$ \\
\hline 11 & 0.595 & 4.42 & $3.80 \times 10^{-5}$ & $3.16 \times 10^{-2}$ \\
\hline 12 & 0.684 & 4.15 & $7.08 \times 10^{-5}$ & $2.99 \times 10^{-2}$ \\
\hline 13 & 0.783 & 3.84 & $1.45 \times 10^{-4}$ & $2.55 \times 10^{-2}$ \\
\hline 14 & 0.839 & 3.56 & $2.76 \times 10^{-4}$ & $1.77 \times 10^{-2}$ \\
\hline 15 & 0.889 & 3.43 & $3.72 \times 10^{-4}$ & $1.39 \times 10^{-2}$ \\
\hline 16 & 0.955 & 3.12 & $7.59 \times 10^{-4}$ & $9.54 \times 10^{-3}$ \\
\hline 17 & 0.982 & 3.06 & $8.71 \times 10^{-4}$ & $7.80 \times 10^{-3}$ \\
\hline 18 & 1.080 & 2.82 & $1.51 \times 10^{-3}$ & $4.88 \times 10^{-3}$ \\
\hline 19 & 1.191 & 2.66 & $2.19 \times 10^{-3}$ & $3.56 \times 10^{-3}$ \\
\hline 20 & 1.489 & 2.29 & $5.13 \times 10^{-3}$ & $2.01 \times 10^{-3}$ \\
\hline 21 & 1.990 & 1.99 & $1.02 \times 10^{-2}$ & $1.15 \times 10^{-3}$ \\
\hline 22 & 2.971 & 1.70 & $2.00 \times 10^{-2}$ & $7.80 \times 10^{-4}$ \\
\hline 23 & 4.909 & 1.45 & $3.55 \times 10^{-2}$ & $7.41 \times 10^{-4}$ \\
\hline 24 & 6.901 & 1.22 & $6.03 \times 10^{-2}$ & $7.01 \times 10^{-4}$ \\
\hline 25 & 0.986 & 2.69 & $2.40 \times 10^{-3}$ & $4.98 \times 10^{-3}$ \\
\hline 26 & 1.081 & 2.34 & $4.57 \times 10^{-3}$ & $2.53 \times 10^{-3}$ \\
\hline 27 & 1.179 & 2.13 & $7.41 \times 10^{-3}$ & $1.84 \times 10^{-3}$ \\
\hline 28 & 1.270 & 1.97 & $1.07 \times 10^{-2}$ & $1.54 \times 10^{-3}$ \\
\hline 29 & 1.479 & 1.75 & $1.78 \times 10^{-2}$ & $1.25 \times 10^{-3}$ \\
\hline 30 & 2.011 & 1.48 & $3.31 \times 10^{-2}$ & $9.20 \times 10^{-4}$ \\
\hline 31 & 3.030 & 1.12 & $7.59 \times 10^{-2}$ & $1.06 \times 10^{-3}$ \\
\hline
\end{tabular}

a For exptl no. 1-24, [M1.97F $]_{0}, 8.38 \times 10^{-2} \mathrm{~mol} / \mathrm{l}$; for exptl no. $25-31$, [M1.97F $]_{0}, 2.514 \times 10^{-1} \mathrm{~mol} / l$.

b Computed from the $\mathrm{pH}$.

Table II. The value of $k$ for $\mathrm{M} 2.95 \mathrm{~F}$ at $35^{\circ} \mathrm{C}$ (The effect of acidity)

Exptla
no. $\underset{\text { molar ratio }}{[\mathrm{MCl}]_{0} /}, \quad \mathrm{HH} \quad \begin{aligned} & {\left[\mathrm{H}^{+}\right],} \\ & \mathrm{mol} / \mathrm{l}\end{aligned} \quad k, 1 / \mathrm{mol} \mathrm{min}$

\begin{tabular}{lllll}
\hline 32 & 0.000 & 8.79 & $1.62 \times 10^{-9}$ & 0.00 \\
33 & 0.023 & 6.23 & $5.90 \times 10^{-7}$ & $3.48 \times 10^{-3}$ \\
34 & 0.034 & 5.97 & $1.07 \times 10^{-6}$ & $5.66 \times 10^{-3}$ \\
35 & 0.053 & 5.72 & $1.91 \times 10^{-6}$ & $9.87 \times 10^{-3}$ \\
36 & 0.103 & 5.34 & $4.58 \times 10^{-6}$ & $1.92 \times 10^{-2}$ \\
37 & 0.203 & 4.90 & $1.26 \times 10^{-5}$ & $4.17 \times 10^{-2}$ \\
38 & 0.302 & 4.64 & $2.29 \times 10^{-5}$ & $6.31 \times 10^{-2}$ \\
39 & 0.404 & 4.36 & $4.37 \times 10^{-5}$ & $7.42 \times 10^{-2}$ \\
40 & 0.505 & 4.11 & $7.77 \times 10^{-5}$ & $8.06 \times 10^{-2}$ \\
41 & 0.548 & 3.97 & $1.07 \times 10^{-4}$ & $8.23 \times 10^{-2}$ \\
42 & 0.609 & 3.90 & $1.26 \times 10^{-4}$ & $7.98 \times 10^{-2}$ \\
43 & 0.706 & 3.64 & $2.29 \times 10^{-4}$ & $7.10 \times 10^{-2}$ \\
44 & 0.801 & 3.37 & $4.26 \times 10^{-4}$ & $6.11 \times 10^{-2}$ \\
45 & 0.909 & 3.13 & $7.41 \times 10^{-4}$ & $4.86 \times 10^{-2}$ \\
46 & 1.000 & 2.91 & $1.23 \times 10^{-3}$ & $3.38 \times 10^{-2}$ \\
47 & 1.121 & 2.71 & $1.95 \times 10^{-3}$ & $2.32 \times 10^{-2}$ \\
48 & 1.329 & 2.48 & $3.31 \times 10^{-3}$ & $1.74 \times 10^{-2}$ \\
49 & 1.523 & 2.29 & $5.14 \times 10^{-3}$ & $1.20 \times 10^{-2}$ \\
50 & 2.008 & 2.05 & $8.92 \times 10^{-3}$ & $7.40 \times 10^{-3}$ \\
51 & 2.990 & 1.74 & $1.82 \times 10^{-2}$ & $4.21 \times 10^{-3}$ \\
52 & 6.129 & 1.33 & $4.68 \times 10^{-2}$ & $2.03 \times 10^{-3}$ \\
53 & 0.868 & 2.86 & $1.38 \times 10^{-3}$ & $3.29 \times 10^{-2}$ \\
54 & 0.932 & 2.68 & $2.09 \times 10^{-3}$ & $2.33 \times 10^{-2}$ \\
55 & 0.979 & 2.55 & $2.82 \times 10^{-3}$ & $2.16 \times 10^{-2}$ \\
56 & 1.056 & 2.33 & $4.68 \times 10^{-3}$ & $1.41 \times 10^{-2}$ \\
57 & 1.152 & 2.16 & $6.92 \times 10^{-3}$ & $1.15 \times 10^{-2}$ \\
58 & 1.281 & 1.99 & $1.02 \times 10^{-2}$ & $9.34 \times 10^{-3}$ \\
59 & 1.479 & 1.82 & $1.51 \times 10^{-2}$ & $6.02 \times 10^{-3}$ \\
60 & 1.675 & 1.68 & $2.09 \times 10^{-2}$ & $4.31 \times 10^{-3}$ \\
61 & 2.000 & 1.55 & $2.82 \times 10^{-2}$ & $3.63 \times 10^{-3}$ \\
62 & 2.959 & 1.22 & $6.03 \times 10^{-2}$ & $2.03 \times 10^{-3}$ \\
\hline
\end{tabular}

a For exptl no. 32-52, [M2.95F $]_{0}, 8.30 \times 10^{-2} \mathrm{~mol} / \mathrm{l}$; for exptl no. 53-62, [M2.95F $]_{0}, 2.490 \times 10^{-1} \mathrm{~mol} / l$. 


\section{Observed Curves}

By the use of the values in Table I for M1.97F and Table II for M2.95F, the observed curves $\left(k\right.$ vs. $\mathrm{pH}, \log k$ vs. $\mathrm{pH}$, and $k$ vs. $\left[\mathrm{H}^{+}\right]$) are obtained, which are shown in Figures 3, 4, and 5 , respectively.

Earlier it had been found by Sato, ${ }^{9}$ one of the authors that the condensation rate of $M 2 F$, $\mathrm{M} 3 \mathrm{~F}$, and $\mathrm{M} 6 \mathrm{~F}$ passes through a maximum. Several years later, ${ }^{10}$ a similar maximum has been confirmed for a study of the condensation of hydroxymethylated 2-methoxy-4, 6-diamino-striazine by Tashiro, et al.

As the above Figures show, not only maximum but also inflection points are found; e.g., the curves $(k$ vs. $\mathrm{pH})$ show one maximum and two inflection points (Figure 3 ), and the curves ( $k$ vs. $\left.\left[\mathrm{H}^{+}\right]\right)$show one maximum and one inflection point (Figure 5). Their values are listed in Table IV.

\section{Rate Equation}

Unlike urea and methylolurea, M1.97F and

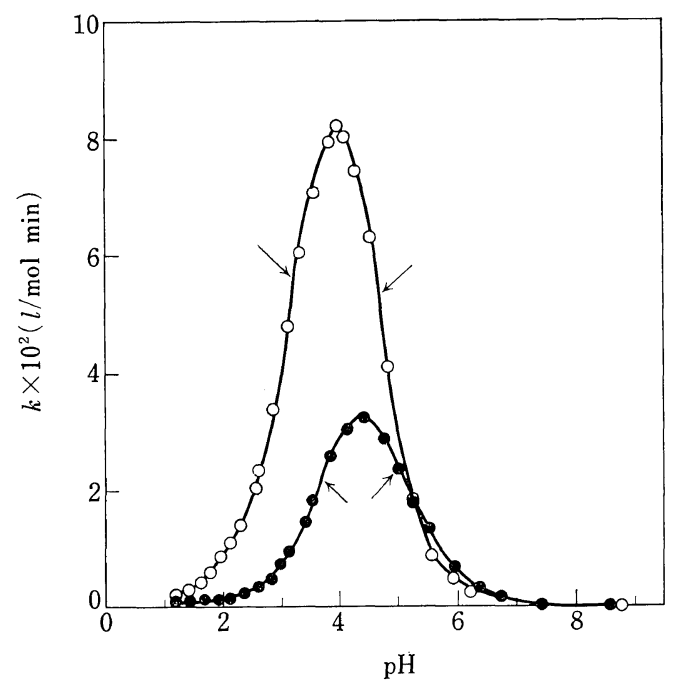

Figure 3. Observed curve $(k$ vs. $\mathrm{pH})$ at $35^{\circ} \mathrm{C}: \rightarrow$, inflection points. 0 ; for $\mathrm{M} 1.97 \mathrm{~F}$ [from right, Table I expt1 no. $1,2,3,4,5,6,7,8,9,10,12,13,14$, $15,16,17,18,19,20$ (in above cases, $[\mathrm{M} 1.97 \mathrm{~F}]_{0}$, $\left.8.38 \times 10^{-2} \mathrm{~mol} / \mathrm{l}\right) 27,28,29,30$, and 31 ([M1.97F $]_{0}$, $\left.2.514 \times 10^{-1} \mathrm{~mol} / l\right)$ ]; $\bigcirc$, for $\mathrm{M} 2.95 \mathrm{~F}$ [from right, Table II exptl no. 32, 33, 34, 35, 36, 37, 38, 39, 40, $41,42,43,44,45\left([\mathrm{M} 2.95 \mathrm{~F}]_{0}, 8.30 \times 10^{-2} \mathrm{~mol} / l\right), 53$, $54,55,56,57,58,59,60,61$, and $62\left([\mathrm{M} 2.95 \mathrm{~F}]_{0}\right.$, $\left.\left.2.490 \times 10^{-1} \mathrm{~mol} / l\right)\right]$.

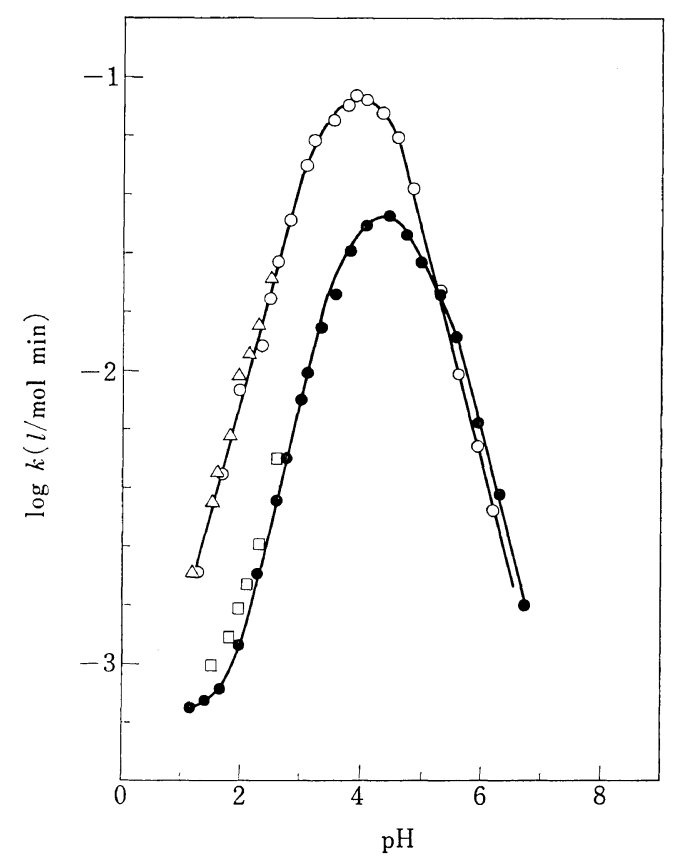

Figure 4. Observed curve $(\log k$ vs. $\mathrm{pH})$ at $35^{\circ} \mathrm{C}$ : -, for M1.97F [from right, Table I exptl no. 3, 4, $5,6,7,8,9,10,12,13,14,15,16,17,18,19,20,21$, $22,23$, and 24 ([M1.97F $\left.]_{0}, 8.38 \times 10^{-2} \mathrm{~mol} / \mathrm{l}\right) ; \square, 25$, $26,27,28,29$ and 30 ([M1.97F $\left.]_{0}, 2.514 \times 10^{-1} \mathrm{~mol} / \mathrm{l}\right)$; the slope, -0.87 at $\left[\mathrm{H}^{+}\right] \ll K_{1}^{-1} ; 0.85$ at $\left[\mathrm{H}^{+}\right] \gg K_{1}{ }^{-1}$ ( $\mathrm{pH}>$ ca. 2)]; $\bigcirc$, for $\mathrm{M} 2.95 \mathrm{~F}$ [from right, Table II expt1 no. 33, 34, 35, 36, 37, 38, 39, 40, 41, 42, 43, $44,45,46,47,48,49,50,51$, and 52 ([M2.95F $]_{0}$, $\left.8.30 \times 10^{-2} \mathrm{~mol} / l\right) ; \triangle: 55,56,57,58,59,60,61$, and $62\left([\mathrm{M} 2.95 \mathrm{~F}]_{0}, 2.490 \times 10^{-1} \mathrm{~mol} / \mathrm{l}\right)$; the slope, -0.82 at $\left[\mathrm{H}^{+}\right] \ll K_{1}^{-1} ; 0.75$ at $\left.\left[\mathrm{H}^{+}\right] \gg K_{1^{-1}}(\mathrm{pH}>c a .2)\right]$.

$\mathrm{M} 2.95 \mathrm{~F}$ as well as $\mathrm{M}$ have sufficient basicities. ${ }^{11}$ This fact made the rate equation complex.

As has been stated previously, ${ }^{6 \mathrm{~b}}$ in an acidic media, the methylolmelamine molecule $\mathrm{MCH}_{2} \mathrm{OH}$ is in equilibrium with the conjugate acid $\mathrm{H}_{\stackrel{+}{\mathrm{M}} \mathrm{CH}} \mathrm{OH}$, and the carbonium ion $\stackrel{\stackrel{+}{\mathrm{C}}}{\mathrm{C}} \mathrm{H}_{2} \cdot{ }^{12}$

$$
\begin{aligned}
& \mathrm{MCH}_{2} \mathrm{OH}+\mathrm{H}^{+} \stackrel{K_{1}}{\rightleftarrows} \mathrm{HMCH}_{2} \mathrm{OH} \\
& \mathrm{MCH}_{2} \mathrm{OH}+\mathrm{H}^{+} \stackrel{K_{2}}{\rightleftarrows} \mathrm{M}^{\stackrel{+}{C}} \mathrm{H}_{2}+\mathrm{H}_{2} \mathrm{O} \\
& \left(K_{1}, K_{2} \text {, equilibrium constant }\right)
\end{aligned}
$$

The condensation at the early stage may proceed among these species (Table III). Therefore, the rate is given by eq 4 , where $k_{1}, k_{2}, k_{3}, k_{4}, k_{5}$, and $k_{6}$ are shown in Table III. Presumably eq 4 


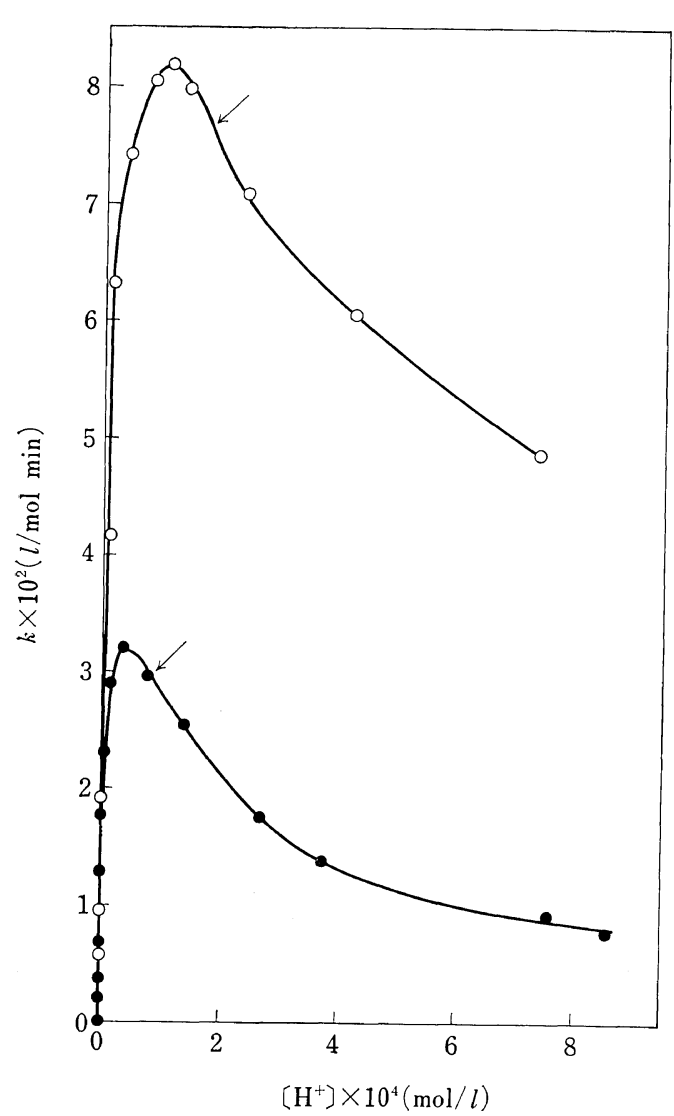

Figure 5. Observed curve $\left(k\right.$ vs. $\left.\left[\mathrm{H}^{+}\right]\right)$at $35^{\circ} \mathrm{C}: \rightarrow$, inflection points; 0 : for M1.97F [from left, Table I exptl no. $1,3,4,5,6,7,8,9,10,12,13,14,15$, 16 , and $\left.17\left([\mathrm{M} 1.97 \mathrm{~F}]_{0}, 8.30 \times 10^{-2} \mathrm{~mol} / l\right)\right] ; \bigcirc$ : for M2.95F [from left, Table II exptl no. 34, 35, 36, $37,38,39,40,41,42,43,44$, and $45\left([\mathrm{M} 2.95 \mathrm{~F}]_{0}\right.$, $\left.\left.2.490 \times 10^{-1} \mathrm{~mol} / l\right)\right]$.

(cf. Condensation Mechanism) would be the ratedetermining step, because there is a maximum
Table III. The rate constants of the elementary reaction for the condensation

\begin{tabular}{lccc}
\hline & $\mathrm{MCH}_{2} \mathrm{OH}$ & $\stackrel{+}{\mathrm{H}} \mathrm{CH}_{2} \mathrm{OH}$ & $\mathrm{M}^{\mathrm{C}} \mathrm{H}_{2}$ \\
\hline $\mathrm{MCH}_{2} \mathrm{OH}$ & $k_{1}$ & $k_{2}$ & $k_{3}$ \\
$\stackrel{+}{\mathrm{H}} \mathrm{CH}_{2} \mathrm{OH}$ & $k_{2}$ & $k_{4}$ & $k_{5}$ \\
$\stackrel{+}{\mathrm{H}} \mathrm{H}_{2}$ & $k_{3}$ & $k_{5}$ & $k_{6}$ \\
\hline
\end{tabular}

in the condensation rate with changing acidity, and also the reaction order is second order in the concentration of $\mathrm{M} 1.97 \mathrm{~F}$ or $\mathrm{M} 2.95 \mathrm{~F}$. If the reactions of eq 2 and 3 which occur before those of eq 4 were rate-determining, the above results would not be obtained.

From the equilibrium between $\mathrm{HM}_{4}^{+} \mathrm{CH}_{2} \mathrm{OH}$ and $\mathrm{M}_{\mathrm{C}}^{\mathrm{C}} \mathrm{H}_{2}$ (cf. eq 2 and 3; $\mathrm{MCH}_{2} \mathrm{OH}=$ intermediate), eq 8 and $8^{\prime}$ can be derived. By the use of $k_{2}{ }^{\prime}$ and $k_{4}{ }^{\prime}$ shown in eq 8 (or $k_{3}{ }^{\prime}$ and $k_{6}{ }^{\prime}$ shown in eq $8^{\prime}$ ), eq 4 can be reduced to eq 5 . This concept is nothing but "ambiguities in kinetics." 13 By the use of $K_{1}, K_{2}$, and eq 9, each portion of eq 10 is given, where " $a$ " denotes the initial concentration $(\mathrm{mol} / l)$ of $\mathrm{M} 1.97 \mathrm{~F}$ or

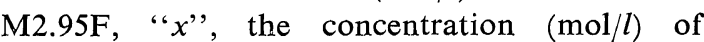
methylene linkage formed after $t \mathrm{~min}$, and " $a-$ $2 x$," the concentration $(\mathrm{mol} / \mathrm{l})$ of $\mathrm{M} 1.97 \mathrm{~F}$ or $\mathrm{M} 2.95 \mathrm{~F}$ after $t$ min. Because this is the early stage of the condensation only dimer formation needs to be discussed here. By the application of eq 10 , eq 5 can be led to eq 6 . From the comparison between eq 6 and 7 , eq 11 is given. Evidently $K_{2}$ is small, whereas $K_{1}{ }^{11}$ is markedly large $\left(K_{1} \gg K_{2}\right)$. Hence, eq 11 can be reduced to eq 12 .

$$
\begin{aligned}
& \text { Rate }=\frac{\mathrm{d} x}{\mathrm{~d} t}=k_{1}\left[\mathrm{MCH}_{2} \mathrm{OH}\right]^{2}+k_{2}\left[\mathrm{MCH}_{2} \mathrm{OH}\right]\left[\stackrel{+}{\mathrm{M} C \mathrm{H}_{2} \mathrm{OH}}\right]+k_{3}\left[\mathrm{MCH}_{2} \mathrm{OH}\right]\left[\stackrel{+}{\mathrm{M}} \mathrm{H}_{2}\right] \\
& +k_{4}\left[\stackrel{+}{\mathrm{H}} \mathrm{CH}_{2} \mathrm{OH}\right]^{2}+k_{5}\left[\stackrel{+}{\mathrm{H}} \mathrm{CH}_{2} \mathrm{OH}\right]\left[\mathrm{M}_{\mathrm{C}}^{+} \mathrm{H}_{2}\right]+k_{6}\left[\mathrm{M}_{\mathrm{C}}^{+} \mathrm{H}_{2}\right]^{2} \\
& =k_{1}\left[\mathrm{MCH}_{2} \mathrm{OH}\right]^{2}+k_{2}{ }^{\prime}\left[\mathrm{MCH}_{2} \mathrm{OH}\right]\left[\stackrel{+}{\mathrm{M} C \mathrm{H}_{2} \mathrm{OH}}\right]\left(\text { or } k_{3}{ }^{\prime}\left[\mathrm{MCH}_{2} \mathrm{OH}\right]\left[\stackrel{+}{\mathrm{M}} \mathrm{CH}_{2}\right]\right) \\
& \left.+k_{4}{ }^{\prime}\left[\mathrm{H}^{+} \mathrm{MCH}_{2} \mathrm{OH}\right]^{2} \text { (or } k_{6}{ }^{\prime}\left[\mathrm{M}^{+} \mathrm{H}_{2}\right]^{2}\right) \\
& =\frac{k_{1}+k_{2}{ }^{\prime} K_{1}\left[\mathrm{H}^{+}\right]\left(\text {or } k_{3}{ }^{\prime} K_{2}\left[\mathrm{H}^{+}\right]\right)+k_{4}{ }^{\prime}\left(K_{1}\left[\mathbf{H}^{+}\right]\right)^{2}\left(\text { or } k_{6}{ }^{\prime}\left(K_{2}\left[\mathrm{H}^{+}\right]^{2}\right)\right.}{\left\{1+\left(K_{1}+K_{2}\right)\left[\mathrm{H}^{+}\right]\right\}^{2}}(a-2 x)^{2} \\
& =k(a-2 x)^{2}
\end{aligned}
$$


Studies on Melamine Resin. VII.

$$
\left.\begin{array}{l}
k_{2}{ }^{\prime}=k_{2}+k_{3} \frac{K_{2}}{K_{1}} \\
k_{4}{ }^{\prime}=k_{4}+k_{5} \frac{K_{2}}{K_{1}}+k_{6}\left(\frac{K_{2}}{K_{1}}\right)^{2} \\
k_{3}{ }^{\prime}=k_{3}+k_{2} \frac{K_{1}}{K_{2}} \\
k_{6}{ }^{\prime}=k_{6}+k_{5} \frac{K_{1}}{K_{2}}+k_{4}\left(\frac{K_{1}}{K_{2}}\right)^{2}
\end{array}\right\}
$$

$$
\left[\mathrm{MCH}_{2} \mathrm{OH}\right]+\left[\mathrm{H}^{\mathrm{H}} \mathrm{CH}_{2} \mathrm{OH}\right]+\left[\mathrm{M}^{\mathrm{C}} \mathrm{H}_{2}\right]=a-2 x
$$

$$
\left.\begin{array}{r}
{\left[\mathrm{MCH}_{2} \mathrm{OH}\right]=\frac{a-2 x}{1+\left(K_{1}+K_{2}\right)\left[\mathrm{H}^{+}\right]}} \\
{\left[\mathrm{HMCH}_{2} \mathrm{OH}\right]=\frac{K_{1}\left[\mathrm{H}^{+}\right](a-2 x)}{1+\left(K_{1}+K_{2}\right)\left[\mathrm{H}^{+}\right]}} \\
{\left[\mathrm{M}^{+} \mathrm{H}_{2}\right]=\frac{K_{2}\left[\mathrm{H}^{+}\right](a-2 x)}{1+\left(K_{1}+K_{2}\right)\left[\mathrm{H}^{+}\right]}}
\end{array}\right\}
$$

\section{Calculated Curves}

Calculated curves corresponding to the above observed ones are described below, where the calculated ones are based on the rate equation given by eq 12 .

Equation 12 is divided in three terms involving $k_{1}, k_{2}{ }^{\prime}$, and $k_{4}{ }^{\prime}(c f$. eq 5). They are represented as $A, B$, and $C$ respectively:

$$
\begin{aligned}
& A=\frac{k_{1}}{\left(1+K_{1}\left[\mathrm{H}^{+}\right]\right)^{2}} \\
& B=\frac{k_{2}{ }^{\prime} K_{1}\left[\mathrm{H}^{+}\right]}{\left(1+K_{1}\left[\mathrm{H}^{+}\right]\right)^{2}} \\
& C=\frac{k_{4}{ }^{\prime}\left(K_{1}\left[\mathrm{H}^{+}\right]\right)^{2}}{\left(1+K_{1}\left[\mathrm{H}^{+}\right]\right)^{2}}
\end{aligned}
$$

From eq 13, 14, and 15, calculated curves for $\mathrm{M} 1.97 \mathrm{~F}$ are graphically shown, where $K_{1}$ of

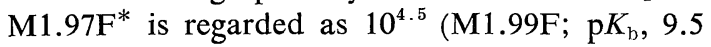

* To $20 \mathrm{ml}$ of an aqueous DMSO solution (the volume ratio: $1 / 4$ ) containing $0.0838 \mathrm{~mol} / \mathrm{l}$ of $\mathrm{M} 1.97 \mathrm{~F}$, $0.1-N$ hydrochloric acid was added at $35^{\circ} \mathrm{C}$. When $S$ was 0.5 , the $\mathrm{pH}$ was 4.5 . As a result, $K_{1}$ for M1.97F would be $10^{4.5}$ since the proton would hardly add to DMSO to form the conjugate acid. ${ }^{6}$ This value agrees with that calculated from the $\mathrm{p} K_{\mathrm{b}}$ of the literature ${ }^{11}$ (aqueous solution). at $\left.25^{\circ} \mathrm{C}\right),{ }^{11}$ viz., the calculated curves $(A, B$ and $C$ vs. $\mathrm{pH}$ ) are shown in Figure 6, those $(\log A, \log B$ and $\log C$ vs. $\mathrm{pH})$ in Figure 7 , and those $\left(A, B\right.$, and $C$ vs. $\left.\left[\mathrm{H}^{+}\right]\right)$in Figure 8.

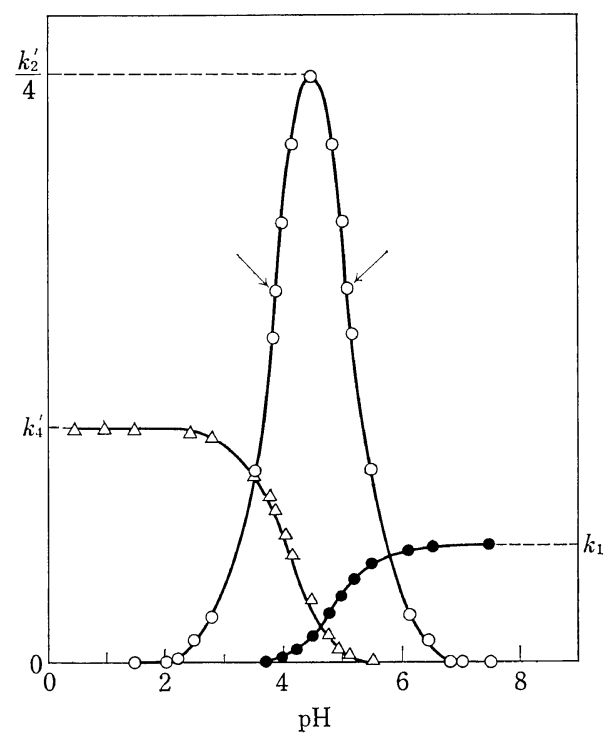

Figure 6. Calculated curves (A, B, and $\mathrm{C}$ vs. $\mathrm{pH}$ ):

-, A; $\bigcirc, \mathrm{B} ; \triangle, \mathrm{C}$; $\rightarrow$, inflection point.

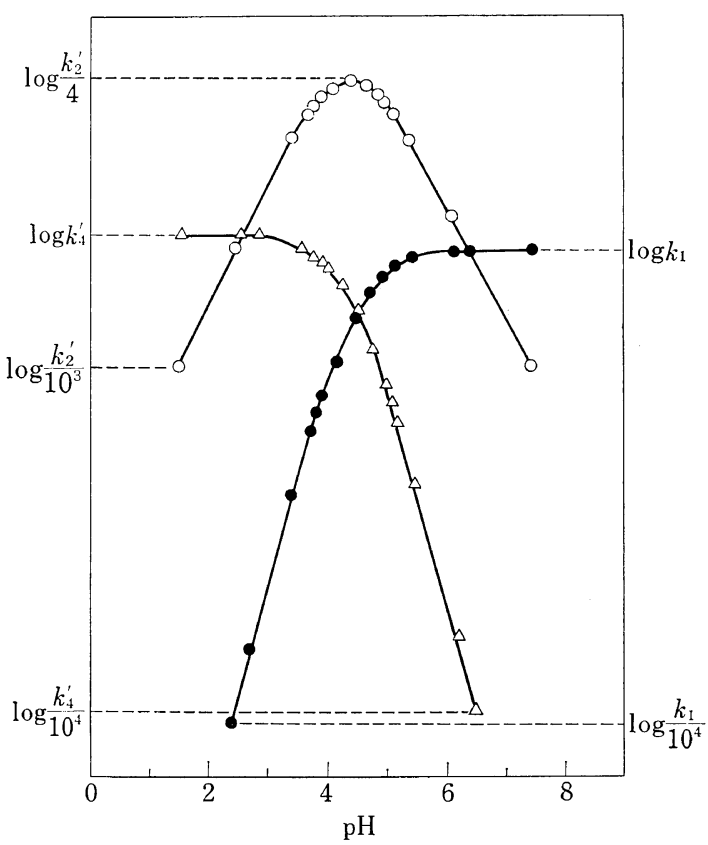

Figure 7. Calculated curves $(\log A, \log B$, and $\log C$ vs. pH): $\quad, \log A ; \bigcirc, \log B ; \triangle, \log C$ : the slope of $(\log B v s$. $\mathrm{pH}),-1.0$ at $\left[\mathrm{H}^{+}\right] \ll K_{1}^{-1} ; 1.0$ at $\left[\mathrm{H}^{+}\right] \gg K_{1}^{-1}$. 


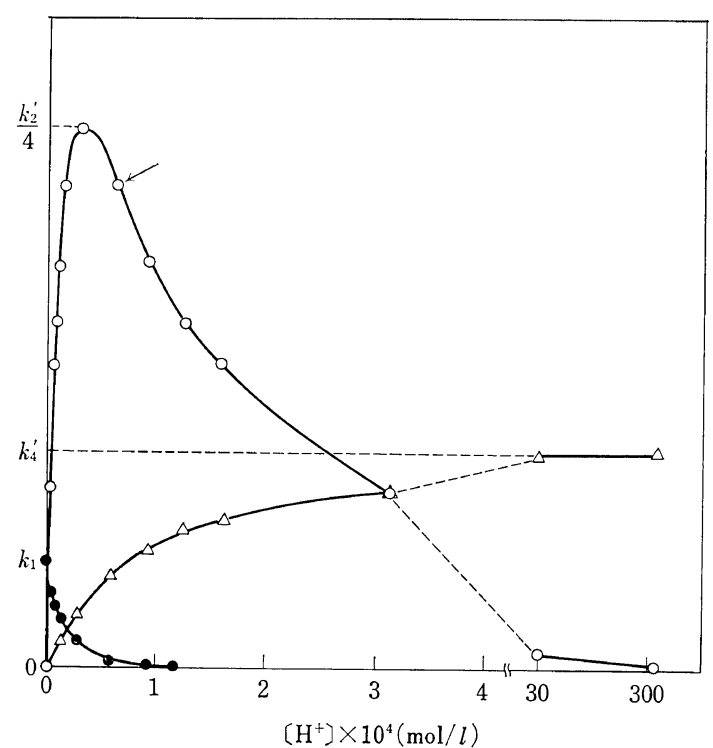

Figure 8. Calculated curves $\left(A, B\right.$, and $C$ vs. $\left.\left[\mathrm{H}^{+}\right]\right)$: ○, $A ; \bigcirc, B ; \triangle, \log C ; \rightarrow$, inflection point.

\section{Condensation Mechanism at the Early Stage}

From the comparison of the above observed curves ( $k$ vs. $\mathrm{pH}, \log k$ vs. $\mathrm{pH}$, and $k$ vs. $\left[\mathrm{H}^{+}\right]$) with the corresponding calculated ones $(A, B$, and $C$ vs. $\mathrm{pH} ; \log A, \log B$, and $\log C$ vs. $\mathrm{pH} ;$ and $A, B$, and $C$ vs. $\left.\left[\mathrm{H}^{+}\right]\right)$respectively, it can be easily estimated which of the reactions $k_{1}, k_{2}{ }^{\prime}$ or $k_{4}{ }^{\prime}$, is the main reaction; as eq 5 shows, the $k_{1}$ reaction is the reaction between two $\mathrm{MCH}_{2} \mathrm{OH}$ molecules, the $k_{2}{ }^{\prime}$ reaction, the reaction of $\mathrm{MCH}_{2} \mathrm{OH}$ with $\mathrm{HM}^{+} \mathrm{CH}_{2} \mathrm{OH}$, and the $k_{4}{ }^{\prime}$ reaction, the reaction of two $\mathrm{HMCH}_{2}^{+} \mathrm{OH}$ molecules.

The condensation mechanism in the presence of acid $(\mathrm{pH}<c a .7 ; \quad S>0)$ was described as follows.

Range of $0<S<1.0$ ( $\mathrm{pH} \mathrm{ca.} \mathrm{2-7).} \mathrm{In} \mathrm{this}$ $\mathrm{pH}$ range, the observed curves do not coincide with the corresponding calculated ones $A$ and $C$. (Figure 3 for M1.97F corresponds to $A$ and $C$ in Figure 6; Figure 4 for $\mathrm{M} 1.97 \mathrm{~F}$, to $\log A$ and $\log C$ in Figure 7; Figure 5 for $\mathrm{M} 1.97 \mathrm{~F}$, to $A$ and $C$ in Figure 8): First, if the main reaction in this $\mathrm{pH}$ range is assumed to be the $k_{1}$ reaction, the $k$ (the observed curves) should decrease with increasing acidity. Second, if the main reaction is assumed to be the $k_{4}{ }^{\prime}$ reaction, the $k$ (the observed curves) should increase with increasing acidity and remain constant at $S>1.0-1.2(\mathrm{pH}<$ ca. 2). But, these assumptions do not coincide with the relationship between $k$ and acidity in the observed curves.

Hence, neither of them is the main reaction. Also, the observed curve (e.g., Figure 3 for $\mathrm{M} 1.97 \mathrm{~F})$ and the only remaining calculated curve $B$ (e.g., Figure 6) are similar to each other. For these reasons, the remaining $k_{2}{ }^{\prime}$ reaction may be the main one.

In view of this, $B$ denoting the $k_{2}^{\prime}$ reaction was investigated in detail.

First, as to the following three curves, the maximum and inflection points are respectively computed.

Curve $(B$ vs. $\mathrm{pH})$

maximum point $(\mathrm{I}),{ }^{*} \mathrm{pH}=\log K_{1}$; inflection points (II), ${ }^{*}$

$$
\mathrm{pH}=\log \frac{K_{1}}{2 \pm \sqrt{ } 3}
$$

Curve $(\log B$ vs. pH)

maximum point (III), ${ }^{*} \mathrm{pH}=\log K_{1}$;

inflection point (IV), ${ }^{*}$ does not exist

(convex curve)

Curve ( $B$ vs. $\left.\left[\mathrm{H}^{+}\right]\right)$

maximum point $(\mathrm{V}),{ }^{*}\left[\mathrm{H}^{+}\right]=K_{1}{ }^{-1}$; inflection point $\left.(\mathrm{VI}),{ }^{*}\left[\mathrm{H}^{+}\right]=2 K_{1}^{-1}\right)$

By the use of eq 16, maximum and inflection points are computed and shown in Table IV, where $K_{1}$ is regarded as $10^{4.5}$ for M1.97F. ${ }^{11}$ The

$$
\begin{aligned}
& \text { * (I) } \frac{\mathrm{d} B}{\mathrm{dpH}}=\frac{\mathrm{d} B}{\mathrm{~d}\left[\mathrm{H}^{+}\right]} \cdot \frac{\mathrm{d}\left[\mathrm{H}^{+}\right]}{\mathrm{dpH}}=0 \\
& \text { (II) } \frac{\mathrm{d}^{2} B}{\mathrm{dpH}^{2}}=\frac{\mathrm{d}}{\mathrm{dpH}}\left(\frac{\mathrm{d} B}{\mathrm{~d}\left[\mathrm{H}^{+}\right]} \cdot \frac{\mathrm{d}\left[\mathrm{H}^{+}\right]}{\mathrm{dpH}}\right)=0 \\
& \text { (III) } \frac{\mathrm{d} \log B}{\mathrm{dpH}}=\frac{\mathrm{d} \log B}{\mathrm{~d}\left[\mathrm{H}^{+}\right]} \cdot \frac{\mathrm{d}\left[\mathrm{H}^{+}\right]}{\mathrm{dpH}}=0 \\
& \text { (IV) } \frac{\mathrm{d}^{2} \log B}{\mathrm{dpH}}=\frac{\mathrm{d}}{\mathrm{dpH}}\left(\frac{\mathrm{d} \log B}{\mathrm{~d}\left[\mathrm{H}^{+}\right]} \cdot \frac{\mathrm{d}\left[\mathrm{H}^{+}\right]}{\mathrm{dpH}}\right)=0 \\
& \text { (V) } \frac{\mathrm{d} B}{\mathrm{~d}\left[\mathrm{H}^{+}\right]}=0 \\
& \text { (VI) } \frac{\mathrm{d}^{2} B}{\mathrm{~d}\left[\mathrm{H}^{+}\right]^{2}}=0
\end{aligned}
$$

Where, e.g., (II) is given as follows

$$
\frac{\mathrm{d}^{2} B}{\mathrm{dpH}^{2}}=\frac{(2.3)^{2} k_{2}^{\prime} K_{1}\left[\mathrm{H}^{+}\right]\left(K_{1}^{2}\left[\mathrm{H}^{+}\right]^{2}-4 K_{1}\left[\mathrm{H}^{+}\right]+1\right)}{\left(K_{1}\left[\mathrm{H}^{+}\right]+1\right)^{4}}
$$


Studies on Melamine Resin. VII.

Table IV. Maximum and inflection points

\begin{tabular}{|c|c|c|c|c|c|}
\hline \multirow{2}{*}{ Curve } & \multirow{2}{*}{$\begin{array}{l}\text { Methylolmel- } \\
\text { amine }\end{array}$} & \multicolumn{2}{|c|}{ Maximum point } & \multicolumn{2}{|c|}{ Inflection point } \\
\hline & & Calculated & Observed & Calculated & Observed \\
\hline \multirow{2}{*}{$B$ vs. $\mathrm{pH}$} & M1.97F & 4.5 & $4.4^{\mathrm{a}}$ & 3.9 and 5.1 & 3.7 and $5.0^{\mathrm{a}}$ \\
\hline & $\mathrm{M} 2.95 \mathrm{~F}$ & 4.1 & $4.0^{\mathrm{a}}$ & 3.5 and 4.6 & 3.2 and $4.7^{\mathrm{a}}$ \\
\hline \multirow[t]{2}{*}{$\log B$ vs. $\mathrm{pH}$} & M1.97F & 4.5 & $4.4^{\mathrm{b}}$ & Not exist & Not exist ${ }^{b}$ \\
\hline & $\mathrm{M} 2.95 \mathrm{~F}$ & 4.1 & $4.1^{b}$ & Not exist & Not exist ${ }^{b}$ \\
\hline \multirow{2}{*}{$B$ vs. $\left[\mathrm{H}^{+}\right]^{\mathrm{d}}$} & M1.97F & $3.2 \times 10^{-5}$ & $3.6 \times 10^{-5 c}$ & $6.3 \times 10^{-5}$ & $7.1 \times 10^{-5 c}$ \\
\hline & M2.95F & $7.9 \times 10^{-5}$ & $1.1 \times 10^{-4 c}$ & $1.6 \times 10^{-4}$ & $1.7 \times 10^{-4 c}$ \\
\hline
\end{tabular}

a Figure 3 at $\mathrm{pH} c a .2-7$.

b Figure 4 at $\mathrm{pH} c a .2-7$.

c Figure 5 at $\mathrm{pH} c a .2-7$.

a $\left[\mathrm{H}^{+}\right], \mathrm{mol} / l$.

calculated curves for M2.95F show the similar form to those of M1.97F, though they were omitted in this paper. Hence, the same was also true for M2.97F, as Figures 3, 4, and 5 for $\mathrm{M} 2.95 \mathrm{~F}$ show. Thus, the results for M2.95F are shown in Table IV together with those of M1.97F, where $K_{1}$ of $\mathrm{M} 2.95 \mathrm{~F}$ is regarded as $10^{4.1}\left(\mathrm{M} 2.97 \mathrm{~F} ; \mathrm{p} K_{\mathrm{b}}, 9.9\right.$ at $\left.25^{\circ} \mathrm{C}\right) .{ }^{11}$

Table IV demonstrates the coincidence of the observed values with the calculated ones for both of maximum and inflection points; ${ }^{*}$ it is seen that the above values are affected by the difference between the $\mathrm{p} K_{\mathrm{b}}$ of $\mathrm{M} 1.97 \mathrm{~F}$ and that of $\mathrm{M} 2.95 \mathrm{~F}$, e.g., the observed maximum for $\mathrm{M} 1.97 \mathrm{~F}$ appears at $\mathrm{pH} 4.4$, but that for $\mathrm{M} 2.95 \mathrm{~F}$, at $\mathrm{pH}$ 4.0.

Second, from eq $14, \log B$ is given by:

$\left[\mathrm{H}^{+}\right] \ll K_{1}{ }^{-1}: \log B \doteqdot-\mathrm{pH}+\log k_{2}{ }^{\prime}+\log K_{1}$

$\left[\mathrm{H}^{+}\right] \gg K_{1}^{-1}: \log B \doteqdot \mathrm{pH}+\log k_{2}{ }^{\prime}-\log K_{1}$

From eq 17 and eq 18 , the slope, $\mathrm{d} \log B / \mathrm{d}$ pH is given to be

* Instead of $B$, when the $k$ shown by eq 12 is used, e.g., the maximum point $\mathrm{d} k / \mathrm{d}\left[\mathrm{H}^{+}\right]=0$, and the inflection point $\mathrm{d}^{2} k / \mathrm{d}\left[\mathrm{H}^{+}\right]^{2}=0$ are given.

Curve $\left(k\right.$ vs. $\left.\left[\mathrm{H}^{+}\right]\right)$ maximum point, $\left[\mathrm{H}^{+}\right]=\frac{k_{2}{ }^{\prime}-2 k_{1}}{K_{1}\left(k_{2}{ }^{\prime}-2 k_{4}\right)} \doteqdot \frac{1}{K_{1}} ;$ inflection point, $\left[\mathrm{H}^{+}\right]=\frac{3 k_{1}-2 k_{2}{ }^{\prime}+k_{4}{ }^{\prime}}{K_{1}\left(2 k_{4}{ }^{\prime}-k_{2}{ }^{\prime}\right)} \div \frac{2}{K_{1}}$

By the use of $k_{1}=0$, and $k_{4}^{\prime}=0\left(k_{2}{ }^{\prime} \gg k_{1}\right.$ and $k_{4}{ }^{\prime}$, $c f$., next section), these are approximately reduced to those for the curve $\left(B v s .\left[\mathrm{H}^{+}\right]\right)$given by eq 16 , respectively.

$$
\begin{array}{ll}
{\left[\mathrm{H}^{+}\right] \ll K_{1}^{-1},} & \frac{\mathrm{d} \log B}{\mathrm{~d} \mathrm{pH}}=-1.0 \\
{\left[\mathrm{H}^{+}\right] \gg K_{1}^{-1},} & \frac{\mathrm{d} \log B}{\mathrm{~d} \mathrm{pH}}=1.0
\end{array}
$$

Thus, the curves $(\log B$ vs. $\mathrm{pH}$ ) should be linear, and their slopes should be $|1.0|$, at $\left[\mathrm{H}^{+}\right] \ll$ $K_{1}^{-1}$ and $\left[\mathrm{H}^{+}\right] \gg K_{1}^{-1}$. With regard to $\mathrm{M} 1.97 \mathrm{~F}$ and M2.95F, Figure 4 shows the straight lines, and their slopes are nearly $|1.0|$, in the range of $\left[\mathrm{H}^{+}\right] \ll K_{1}^{-1}$ and $\left[\mathrm{H}^{+}\right] \gg K_{1}^{-1}$ with $\mathrm{pH} \quad \mathrm{ca} .2-7$ (somewhat smaller than $|1.0|$ ).

Such numerous kinetic evidences stated above strongly support that the main reaction in this $\mathrm{pH}$ range is the $k_{2}^{\prime}$ reaction.

Range of $S>1.0-1.2 \quad(p H<c a .2)$. Since $\mathrm{M} 1.97 \mathrm{~F}$ and $\mathrm{M} 2.95 \mathrm{~F}$ have sufficient basicities ${ }^{11}$ to combine with an equivalent amount of hydrochloric acid to form $\mathrm{HM}^{+} \mathrm{CH}_{2} \mathrm{OH}$, the concentration of $\mathrm{MCH}_{2} \mathrm{OH}$ at $S>1.0-1.2$ is extremely small.

In this $\mathrm{pH}$ range $(S>1.0-1.2 ; \mathrm{pH}<c a .2)$, the observed curves (e.g., Figure 3 ) do not coincide with the corresponding calculated one $B$ (e.g., Figure 6); i.e., if the main reaction in this $\mathrm{pH}$ range is the $k_{2}{ }^{\prime}$ reaction as in the range of $0<S<1.0, k$ of the observed curves in this $\mathrm{pH}$ range (Figure 3 ) should be considerably smaller. Accordingly, the $k_{2}{ }^{\prime}$ reaction would not be the main reaction. Similarly, the $k_{1}$ reaction is not the main one. Hence, the only one remaining, the $k_{4}{ }^{\prime}$ reaction would be the main reaction, as speculated by Sato. ${ }^{6 a, b}$

While the calculated curve $C$ remains constant 


\section{K. SAto and T. NaIto}

at $\mathrm{pH}<c a .2$ (Figures 6 and 7), the $k$ of the observed one decreases slightly and the $k$ of $\mathrm{M} 2.95 \mathrm{~F}$ decreases more markedly with increasing acidity than that of M1.97F (Figure 3). This discrepancy would be interpreted as follows. In this study, the decomposition of $\mathrm{M} 1.97 \mathrm{~F}$ and $\mathrm{M} 2.95 \mathrm{~F}$ was considerably supressed by the use of an aqueous DMSO media; this result has been stated in a previous paper. ${ }^{6 b}$ But, from this study, it was revealed by using the sulfite method that the decomposition rate of $\mathrm{M} 1.97 \mathrm{~F}$ and $\mathrm{M} 2.95 \mathrm{~F}$ increase somewhat with increasing acidity, and also the decomposition rate of $\mathrm{M} 2.95 \mathrm{~F}$ is faster than that of $\mathrm{M} 1.97 \mathrm{~F}$, in this $\mathrm{pH}$ range.* This data is similar to that of di- and trimethylolacetoguanamine. ${ }^{14}$ Furthermore, as is found in the next section, the condensation rate of $\mathrm{M} 2.95 \mathrm{~F}$ is remarkably larger than that of M1.97F at the same $S$. As a result, with increasing acidity, the $k$ of $\mathrm{M} 2.95 \mathrm{~F}$ would decrease more markedly than that of M1.97F even though the $k_{4}{ }^{\prime}$ reaction is the main reaction. Thus, this discrepancy can be explained.

In a previous paper by Sato, ${ }^{6 \mathrm{a}, \mathrm{b}}$ the $k_{4}{ }^{\prime}$ reaction at $S>1.0-1.2$ has been estimated for the condensation of methylolmelamine. The condensation of methylolacetoguanamine has recently been studied at $\mathrm{pH} \mathrm{3-7}$ by Uragami, et al. ${ }^{15}$ but the similar $k_{4}^{\prime}$ reaction is not estimated in this $\mathrm{pH}$ range. However, the similar $k_{4}{ }^{\prime}$ reaction has been confirmed at $\mathrm{pH} 1.2$ in the study of the condensation of hydroxymethylated 2-methoxy4,6-diamino-s-triazine by Tashiro; ${ }^{16}$ thus this consideration has been supported by Tashiro.

In addition, on the basis of the electronic theory, the above consideration may be acceptable: Surely $k_{2}{ }^{\prime}$ is markedly larger than $k_{1}$ and $k_{4}{ }^{\prime}{ }^{6 \mathrm{~b}} \mathrm{But}$, at $\mathrm{pH}<c a .2$, the $k_{4}{ }^{\prime}$ reaction would be the main reaction, because the concentration of $\mathrm{MCH}_{2} \mathrm{OH}$, which is the active species for both $k_{1}$ and $k_{2}{ }^{\prime}$ reactions (see eq 5), is extremely small at $\mathrm{pH}<c a .2$.

Comparison between the Condensation Rate of M1.97F and M2.95F

Previously, the condensation rate between mono- and dimethylolurea has been compared

* A part of this work was presented by K. Sato, et al., SPSJ 20th Symposium on Macromolecules, November 1971, and the detail will be reported later. at "the same $\mathrm{pH}^{2}$ " of the media (pH 4.0) by De Jong, et $a l .{ }^{10}$. Hence, the same comparison was made between the $k$ of M1.97F and the $k$ of M2.95F. As shown in Figure 3, at the same $\mathrm{pH}<c a .5$, the $k$ of $\mathrm{M} 2.95 \mathrm{~F}$ is remarkably larger than the $k$ of $\mathrm{M} 1.97 \mathrm{~F}$, notwithstanding, they are nearly equal to each other at $\mathrm{pH}>c a .5$.

But for methylolmelamine, the above comparison is unsuitable, because the $\mathrm{p} K_{\mathrm{b}}$ of $\mathrm{M} 1.97 \mathrm{~F}$ differs considerably from that of $\mathrm{M} 2.95 \mathrm{~F},{ }^{11}$ not similar to those of mono- and dimethylolurea.

Obviously, the molar ratios of $\left[\mathrm{H}^{+} \mathrm{MCH}_{2} \mathrm{OH}\right]_{0} /$ $\left[\mathrm{MCH}_{2} \mathrm{OH}\right]_{0}$ for $\mathrm{M} 1.97 \mathrm{~F}$ are respectively the same as those for $\mathrm{M} 2.95 \mathrm{~F}$, so far as $S$ is the same for each. Therefore, the comparison of $k$ at "the same $S$ " would be suitable in this case; the $k$ of $\mathrm{M} 2.95 \mathrm{~F}-k$ of $\mathrm{M} 1.97 \mathrm{~F}$ ratio at the same $S$ means the $k_{2}{ }^{\prime}$ of $\mathrm{M} 2.95 \mathrm{~F}-k_{2}{ }^{\prime}$ of $\mathrm{M} 1.97 \mathrm{~F}$ ratio at $0<S<1.0$ since the main reaction in this range is the $k_{2}{ }^{\prime}$ reaction (also see eq 5), and the $k_{4}{ }^{\prime}$ of $\mathrm{M} 2.95 \mathrm{~F}-k_{4}{ }^{\prime}$ of $\mathrm{M} 1.97 \mathrm{~F}$ ratio at $S>1.0-1.2$ since the main reaction in this range seems to be the $k_{4}{ }^{\prime}$ reaction (also see eq 5). This comparison is shown in Figure 9.

As shown in Figure 9, at the same $S$, the $k$ of $\mathrm{M} 2.95 \mathrm{~F}$ is remarkably larger than that of M1.97F in any acidity. Also, at the same $S$, the $k$ of $\mathrm{M} 2.95 \mathrm{~F}-k$ of $\mathrm{M} 1.97 \mathrm{~F}$ ratios at $S>$ $1.0-1.2$ are more larger than those at $0<S<1.0$. In detail, at $0<S<1.0$, the $k$ of $\mathrm{M} 2.95 \mathrm{~F}$ is nearly three times larger than that of M1.97F, i.e., the $k_{2}{ }^{\prime}$ of $\mathrm{M} 2.95 \mathrm{~F}-k_{2}{ }^{\prime}$ of $\mathrm{M} 1.97 \mathrm{~F}$ ratios keep nearly constant at 3 to 1 in this range. Contrarily, at $S>1.0-1.2$, the $k$ of $\mathrm{M} 2.95 \mathrm{~F}$ is nearly six times larger than that of $\mathrm{M} 1.97 \mathrm{~F}$, i.e., the $k_{4}{ }^{\prime}$ of $\mathrm{M} 2.95 \mathrm{~F}-k_{4}{ }^{\prime}$ of $\mathrm{M} 1.97 \mathrm{~F}$ ratios keep nearly constant at 6 to 1 in this range. This finding suggests the difference between the condensation mechanism in the range of $0<S<1.0$ and that in $S>1.0-1.2$ for M1.97F and M2.95F.

De Jong, et al., ${ }^{1 \mathrm{e}}$ have reported that the condensation rate of monomethylolurea is greatly larger than that of dimethylolurea. From this, they stated that the reaction of eq 21 is greatly faster than that of eq 22, viz., the $\mathrm{N}$ of the amino group is greatly reactive (nucleophilic) than the $\mathrm{N}$ of the aminomethylol group. Therefore, the result obtained for M1.95F and M2.95F is "apparently" opposite to the case of mono- 


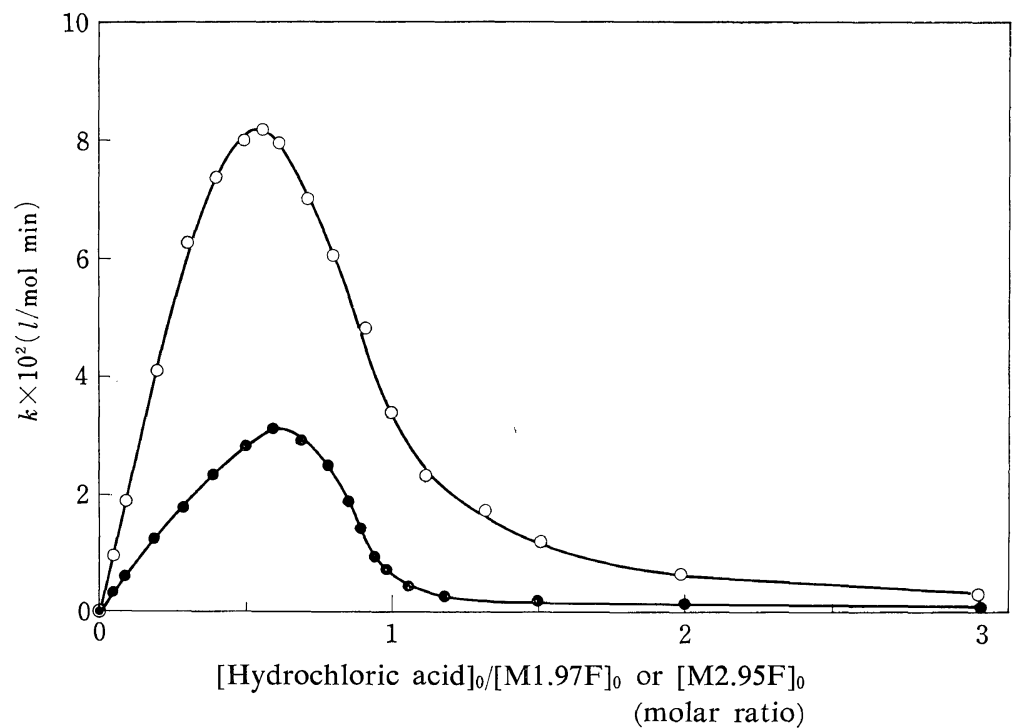

Figure 9. Comparison between the $k$ of $\mathrm{M} 1.97 \mathrm{~F}$ and $k$ of $\mathrm{M} 2.95 \mathrm{~F}$ at the same $\mathrm{S}$ and $35^{\circ} \mathrm{C}$ : $\boldsymbol{0}$, for M1.97F [from left, Table I expt1 no. 1, 4, 5, 6, 7, 8, 9, 10, 12, 13, 14, 15, 16, 17, 18, 19, 20, 21, and 22 ( $\left.\left.[\mathrm{M} 1.97 \mathrm{~F}]_{0}, 8.38 \times 10^{-2} \mathrm{~mol} / l\right)\right] ; \quad \bigcirc$, for M2.95F [from left, Table II exptl no. 32, 35, 36, 37, 38, $39,40,41,42,43,44,45,46,47,48,49,50$, and $\left.51\left([\mathrm{M} 2.95 \mathrm{~F}]_{0}, 8.30 \times 10^{-2} \mathrm{~mol} / l\right)\right]$.

and dimethylolurea, since M2.95F has scarcely amino group.
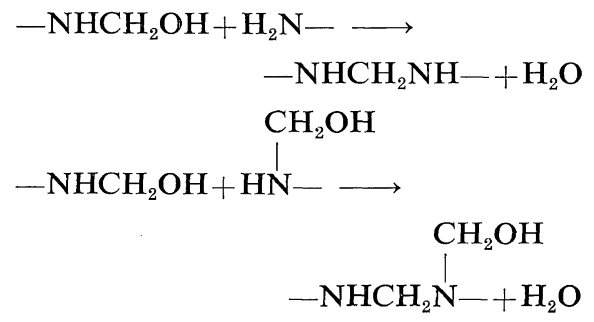

This finding can be interpreted as follows. The $k_{2}{ }^{\prime}$ and $k_{4}{ }^{\prime}$ reaction schemes for M2F would be formulated in eq 23 and 24 , respectively; those for $\mathrm{M} 3 \mathrm{~F}$, in eq 25 and 26 , respectively, where the structure of the conjugate acid of methylolmelamine has been used as given by Dixon, et al. ${ }^{11}$

Range of $0<S<1.0$. The main reaction in this range is the $k_{2}^{\prime}$ reaction. Accordingly, the $k_{2}{ }^{\prime}$ reaction schemes between $\mathrm{M} 2 \mathrm{~F}$ and $\mathrm{M} 3 \mathrm{~F}$ were compared.

With regard to M2F, as eq 23 formulates, the condensation of the $k_{2}{ }^{\prime}$ reaction would proceed mainly between "the $\mathrm{C}$ of the methylol group apart from the $\mathrm{N}$ " in $\mathrm{H}^{+} \mathrm{CH}_{2} \mathrm{OH}$ and "the $\mathrm{N}$ of the amino group" in $\mathrm{MCH}_{2} \mathrm{OH}$. However, with regard to $\mathrm{M} 3 \mathrm{~F}$, as eq 25 formulates, the condensation of the $k_{2}{ }^{\prime}$ reaction would proceed mainly between "the $\mathrm{C}$ of the methylol group neighboring the $\stackrel{+}{\mathrm{N}}$ " in $\mathrm{H}_{\mathrm{M}}^{+} \mathrm{CH}_{2} \mathrm{OH}$ and "the $\mathrm{N}$ of the aminomethylol group" in $\mathrm{MCH}_{2} \mathrm{OH}$.

The condensation rate would be faster, with increase of the electrophilic effect of the $C$ of the methylol group and/or the nucleophilic effect of the $\mathrm{N}$ of the amino group or aminomethylol group. In this case, the above $\mathrm{C}$ in $\mathrm{H}^{+} \mathrm{CH}_{2} \mathrm{OH}$ for M3F more markedly shows electrophilic effects, i.e., more marked reactivity than the above $\mathrm{C}$ in $\mathrm{HMCH}_{2} \mathrm{OH}$ for M2F. On the other hand, the above $\mathrm{N}$ of the aminomethylol group in $\mathrm{MCH}_{2} \mathrm{OH}$ for $\mathrm{M} 3 \mathrm{~F}$ would show less nucleophilic effect, i.e., less reactivity than the above $\mathrm{N}$ of the amino group in $\mathrm{MCH}_{2} \mathrm{OH}$ for $\mathrm{M} 2 \mathrm{~F}$, and similar to those of methylolurea. ${ }^{\text {1e }}$ Therefore, these effects are opposite each other for the condensation of the $k_{2}{ }^{\prime}$ reaction of M3F. Since "the effect of the C" is larger than "the effect of the $\mathrm{N}$ " on the rate, it is interpreted that in this range the $k$ of $\mathrm{M} 2.95 \mathrm{~F}$ shows larger values than $k$ of $\mathrm{M} 1.97 \mathrm{~F}$ at the same $S$.

The effect of the $\mathrm{N}$ would be discussed in detail as follows. With regard to hydroxymeth- 
K. SAto and T. Naito<smiles>N[C@H]1N=C(NCO)N=C(NCO)N1</smiles>

$\left(\stackrel{+}{\mathrm{H}} \mathrm{CH}_{2} \mathrm{OH}\right.$ of $\left.\mathrm{M} 2 \mathrm{~F}\right)$<smiles>C#CCNc1nc(N)nc(NCO)n1</smiles>

$\left(\mathrm{MCH}_{2} \mathrm{OH}\right.$ of $\left.\mathrm{M} 2 \mathrm{~F}\right)$

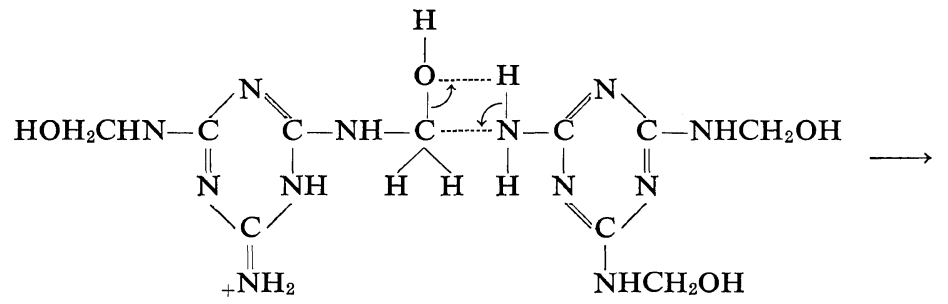<smiles>C#CONC1N=C(N)NC(NCNc2nc(NCO)nc(NCO)n2)NC1N</smiles><smiles>NC1N=C(NC=O)NC(NCNc2nc(NCO)nc(NCO)n2)N1</smiles><smiles>C=C=[N+]=C1N=C(NC=[NH2+])N=C(NCO)NC1NCO</smiles>

( $\stackrel{+}{\mathrm{M}} \mathrm{CH}_{2} \mathrm{OH}$ of $\left.\mathrm{M} 2 \mathrm{~F}\right)$

$\left(\stackrel{+}{\mathrm{M}} \mathrm{CH}_{2} \mathrm{OH}\right.$ of $\left.\mathrm{M} 2 \mathrm{~F}\right)$

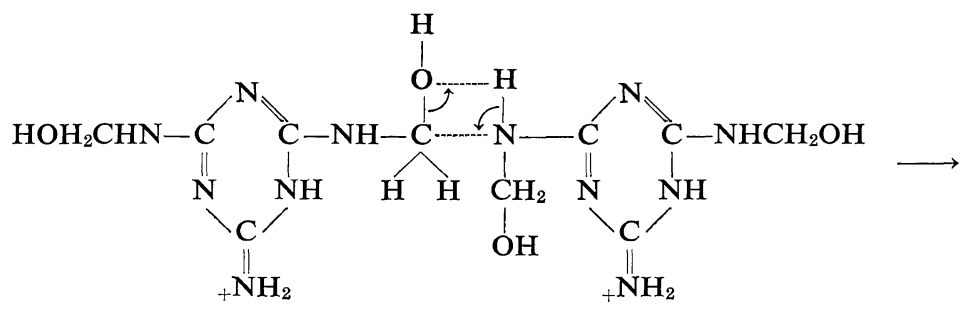<smiles>N[C@H]1N=C(NCO)N=C(NCO)N1</smiles> 
Studies on Melamine Resin. VII.

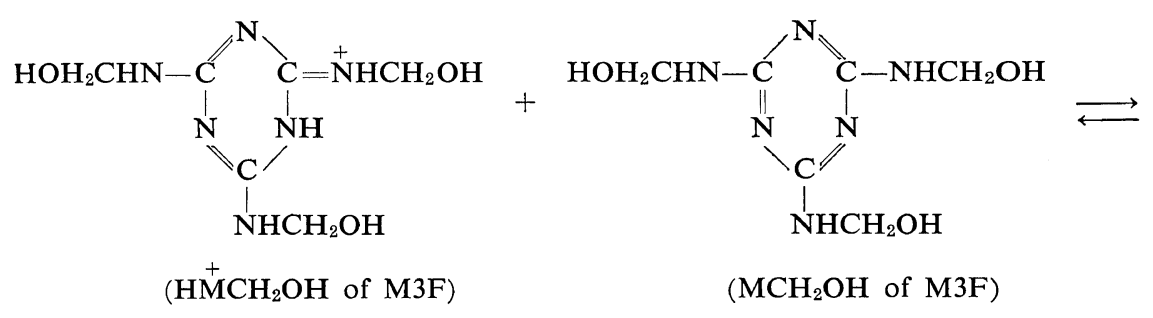<smiles>[2H]C(N[C@@H]1N=C(NCO)N=C(NCO)N1)N(CO)c1nc(NCO)nc(NCO)n1</smiles><smiles>OCNc1nc(NCO)nc(NCO)n1</smiles><smiles>OCNc1nc(N=CNc2nc(NCO)nc(NCO)n2)nc(NCO)n1</smiles>

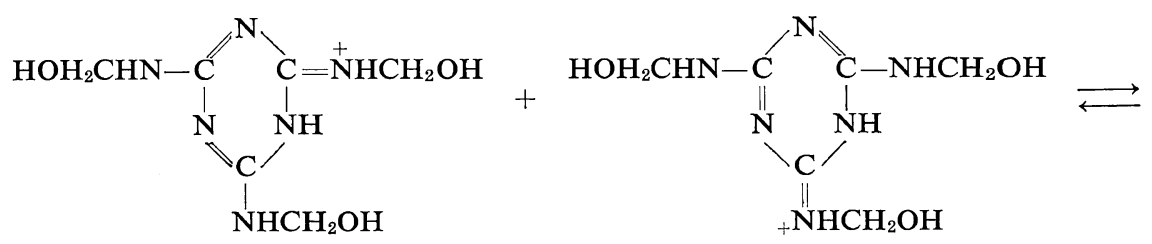

$\left(\stackrel{+}{\mathrm{M}} \mathrm{CH}_{2} \mathrm{OH}\right.$ of $\left.\mathrm{M} 3 \mathrm{~F}\right)$ ( $\stackrel{+}{\mathrm{M}} \mathrm{CH}_{2} \mathrm{OH}$ of $\left.\mathrm{M} 3 \mathrm{~F}\right)$

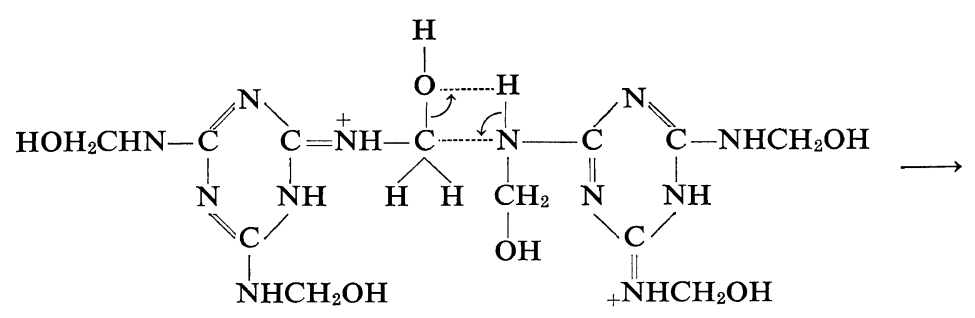<smiles>OCNc1nc(NCO)nc([NH2+]CO)n1</smiles> 


\section{K. SAto and T. Naito}

ylation, the functionality of $\mathrm{M}$ has been observed to be 6 against $F$, but the functionality of urea, only $2.4^{17}$. Similarly, it has been indicated that $\mathrm{M}^{12,18}$ easily reacts with $\mathrm{F}$ to form $\mathrm{M} 3 \mathrm{~F}$, in addition, to form M6F in the concentrated $\mathrm{F}$ media, whereas urea $^{17,19}$ readily forms dimethylolurea but forms tetramethylolurea with marked difficulty. These results suggest that the $\mathrm{N}$ of the aminomethylol group in methylolurea would be greatly less nucleophilic than the $\mathrm{N}$ of the amino group in urea. However, the $\mathrm{N}$ of the aminomethylol group in $\mathrm{MCH}_{2} \mathrm{OH}$ of methylolmelamine would not be markedly less nucleophilic than the $\mathrm{N}$ of the amino group in $\mathrm{M}^{17}$, presumably due to the difference in the characteristics of the basicity between urea and $M$ as has been speculated previously. ${ }^{3,20}$

With regard to condensation, the same would be also true, since the rate constant of dimethylolurea is less than one-two thousandth ${ }^{1 \mathrm{e}}$ of that of monomethylolurea at $35^{\circ} \mathrm{C}$ and $\mathrm{pH}$ 4.0.

If the $\mathrm{N}$ of the aminomethylol group in $\mathrm{MCH}_{2} \mathrm{OH}$ for M3F shows significantly less nucleophilic effect than the $\mathrm{N}$ of the amino group in $\mathrm{MCH}_{2} \mathrm{OH}$ for $\mathrm{M} 2 \mathrm{~F}$, the above result on the $k$ of $\mathrm{M} 2.95 \mathrm{~F}-k$ of $\mathrm{M} 1.97 \mathrm{~F}$ ratio would not be obtained, because the effect of the $\mathrm{N}$ may be larger than that of the $\mathrm{C}$ in this case. (Thus, the condensation of methylolmelamine would be proceeded not only by the reaction of eq 21 to a major extent, but also by that of eq 22. For this reason, unlike methylolurea, ${ }^{1 \mathrm{e}}$ it is complex to consider the reactivity of the respective functional group; hence, it has not been discussed in this paper.)

Range of $S>1.0-1.2$. The $k_{4}{ }^{\prime}$ reaction scheme of M2F was compared with that of M3F, since $k_{4}{ }^{\prime}$ reaction would be the main reaction in this range.

As to M2F, as eq 24 formulates, the condensation of the $k_{4}{ }^{\prime}$ reaction would proceed mainly between "the $\mathrm{C}$ of the methylol group apart from the $\stackrel{+}{\mathrm{N}}$ " in $\mathrm{H}^{\mathrm{M}} \mathrm{CH}_{2} \mathrm{OH}$ and "the $\mathrm{N}$ of the aminomethylol group" in $\mathrm{HM}^{+} \mathrm{CH}_{2} \mathrm{OH}$. But, for $\mathrm{M} 3 \mathrm{~F}$, as eq 26 formulates, the condensation of the $k_{4}{ }^{\prime}$ reaction would proceed mainly between "the $\mathrm{C}$ of the methylol group neighboring the $\stackrel{+}{\mathrm{N}}$ " in $\mathrm{HM}_{\mathrm{M}}^{+} \mathrm{CH}_{2} \mathrm{OH}$ and "the $\mathrm{N}$ of the aminomethylol group" in $\mathrm{HM}^{+} \mathrm{CH}_{2} \mathrm{OH}$. Thus, the above $\mathrm{C}$ in $\mathrm{HMCH}_{2}^{+} \mathrm{OH}$ for $\mathrm{M} 2 \mathrm{~F}$ and that for $\mathrm{M} 3 \mathrm{~F}$ react with "the $\mathrm{N}$ of the same aminomethylol group" in the respective $\mathrm{HM}^{+} \mathrm{CH}_{2} \mathrm{OH}$, unlike the case of $0<S<1.0$. Hence, the effects of the $\mathrm{N}$ would be negligible. As indicated, the above $\mathrm{C}$ in $\mathrm{HM}^{+} \mathrm{CH}_{2} \mathrm{OH}$ of $\mathrm{M} 3 \mathrm{~F}$ is more reactive than the above $\mathrm{C}$ in $\mathrm{HM}^{+} \mathrm{CH}_{2} \mathrm{OH}$ of $\mathrm{M} 2 \mathrm{~F}$, as is the case in the range $0<S<1.0$. Consequently, it is considered that in the $S>1.0-1.2$ range the $k$ of $\mathrm{M} 2.95 \mathrm{~F}-k$ of M1.95F ratios at the same $S$ show larger values than those in the range of $0<S<1.0$.

Acknowledgment. The authors wish to thank Dr. Y. Abe, Mr. K. Sugawara, Mr. K. Saito and Mr. H. Negishi of our laboratory for the technical assistance in this work.

\section{REFERENCES}

1. (a) H. Kadowaki, Osaka Kogyo Gijutsu Shikensho Hokohu, 13, 27 (1932); (b) G. Smeth and A. Borzee, J. Polym. Sci., 8, 371 (1952); (c) S. Takahashi, Kobunshi Kagaku (Chem. High Polymers), 9, 53 (1952); (d) S. Kuriyama, E. Hamada, and M. Takenouchi, Kogyo Kagaku Zasshi ( $J$. Chem. Soc. Japan, Ind. Chem. Sect.), 55, 33 (1952); (e) J. I. De Jong and J. De Jonge, Rec. Trav. Chem., 72, 139 (1953).

2. T. Kitagawa, Kogyo Kagaku Zasshi (J. Chem. Soc. Japan, Ind. Chem. Sect.), 53, 181 (1950).

3. H. P. Wohnsiedler,, Ind. Eng. Chem., 44, 2679 (1952).

4. K. Koeda, Kogyo Kagaku Zasshi (J. Chem. Soc. Japan, Ind. Chem. Sect.), 60, 1567 (1957).

5. N. Yoshimi, S. Yamao, M. Kawakita, and M. Tanaka, ibid., 66, 279 (1963).

6. (a) K. Sato, Bull. Chem. Soc. Japan, 40, 2963 (1967); (b) ibid., 41, 7 (1968).

7. J. I. Levenson, Ind. Eng. Chem. Anal. Ed., 12, 332 (1940).

8. K. Sato, Bull. Chem. Soc. Japan, 40, 1547 (1967).

9. A part of this work was presented by K. Sato at the 11th Annual Meeting of the Society of Polymer Science, May, 1962.

10. T. Tashiro, et al., presented at the 20th Annual Meeting of the Chemical Society of Japan, April, 1967; T. Tashiro and M. Yasuda, Kobunshi Kagaku (Chem. High. Polymers), 25, 400 (1968).

11. J. K. Dixon, N. T. Woodberry, and G.W. 
Costa, J. Amer. Chem. Soc., 69, 599 (1947).

12. M. Okano and Y. Ogata, ibid., 74, 5728 (1952).

13. E.S. Gould, "Mechanism and Structure in Organic Chemistry" Henry Hold Co., Inc., New York, N.Y., 1959, p 187.

14. T. Uragami and M. Oiwa, Kogyo Kagaku Zasshi (J. Chem. Soc. Japan, Ind. Chem. Sect.), 73, 611 (1970).

15. T. Uragami and M. Oiwa, ibid., 73, 621 (1970).

16. T. Tashiro, Kobunshi Kagaku (Chem. High Polymers) 27, 530 (1970).
17. K. Koeda, ibid., 16, 62 (1959).

18. K. Sato, Kogyo Kagaku Zasshi (J. Chem. Soc. Japan, Ind. Chem. Sect.), 72, 1911 (1969).

19. H. Kadowaki, Osaka Kogyo Gijutsu Shikensho Hokoku, 16, No. 6 (1935); 17, No. 3 (1936); M. Hamada, Kogyo Kagaku Zasshi (J. Chem. Soc. Japan, Ind. Chem. Sect.), 58, 286 (1955).

20. G. A. Crowe and C. C. Lynch, J. Amer. Chem. Soc., 70, 3795 (1949); L. E. Smythe, ibid., 75, 574 (1953); K. Sato, Bull. Chem. Soc. Japan, 40, 724 (1967). 